\title{
Analiza możliwości rozszerzenia zakresu stosowania hamulca klockowego w modernizowanych i nowych pojazdach trakcyjnych
}

\begin{abstract}
W najbliższej przyszłości hamulce tarczowe i klockowe będq nadal podstawowa forma układów hamulcowych sterowanych pneumatycznie $w$ trakcyjnych pojazdach szynowych. Hamulce tarczowe pozostana przede wszystkim hamulcami realizujacymi duze moce hamowania. W pojazdach o prędkościach maksymalnych $120 \mathrm{~km} / \mathrm{h}$ oraz $w$ ściśle określonych warunkach brzegowych na większe prędkości, hamulec klockowy jest nadal interesujacy ze względu na niskie koszty produkcji i niskie koszty eksploatacji. W artykule przedstawiono czynniki majace wptyw na zakres stosowalności hamulca klockowego $w$ aspekcie cieplnych uszkodzeń kół oraz warunki brzegowe jego stosowania, dla różnych rodzajów materiałów wstawek hamulca klockowego.
\end{abstract}

\section{Wstęp}

Aktualnie i w najbliższej przyszłości układ hamulca pneumatycznego w pojazdach trakcyjnych komunikacji regionalnej i dalekobieżnej, a z całą pewnością w pociagach ciagnionych przez lokomotywy nie będzie mógł być zastapiony w pełni innymi układami. Sprężone powietrze, jako medium, jest konieczne nie tylko do wytworzenia siły hamowania, ale również jest używane w klasycznym wykonaniu hamulca pneumatycznego jako czynnik sterowania hamulcami w całym pociagu. Szczególnie w długich pociagach z powodu skończonych prędkości rozchodzenia się fali hamowania w przewodzie głównym, powstają problemy wynikające $\mathrm{z}$ coraz późniejszego wejścia do pracy hamulców wzdłuż pociągu, co prowadzi do wydłużenia drogi hamowania, a dla małych prędkości pociagu do pojawienia się znacznych sił wzdłużnych, które powodować mogą niejednokrotnie uszkodzenia wagonów oraz wykolejenia. Eliminowanie tych wad realizowane jest od dawna przez zastosowanie w hamulcach UIC nastawienia ,pospieszny”, „osobowy” czy „towarowy” (w zależności od potrzeb eksploatacyjnych), albo przez zastosowanie hamulców sterowanych elektrycznie (hamulce EP $\mathrm{w}$ zespołach trakcyjnych i pociągach na duże prędkości). Współczesne pojazdy trakcyjne są dzisiaj często dodatkowo wyposażane w hamulec elektrodynamiczny (ED), aby:

- ograniczyć stosowanie hamulców ciernych sterowanych pneumatycznie tak, by zmniejszyć zużycie par ciernych (wstawek hamulca klockowego, powierzchni tocznej kół lub okładzin ciernych i tarcz hamulcowych) poprzez zmniejszenie do minimum energii rozpraszanej przez te układy,
- odzyskana energia podczas hamowania ( $\mathrm{z}$ energii kinetycznej) mogła być wykorzystana do napędu innych pojazdów lub innych odbiorników energii.

Dzięki zastosowaniu hamulca ED zwiększa się wielokrotnie żywotność par ciernych, a co za tym idzie zmniejszają się bardzo istotnie koszty eksploatacji.

Mimo powszechnego stosowania elektropneumatycznych i elektrodynamicznych układów hamulca, z hamulca pneumatycznego nadal nie można zrezygnować ze względów bezpieczeństwa. Nie tylko dlatego, że awaria tych hamulców nie jest wykluczona, ale również dlatego, że względnie proste jest wykazanie właściwego bezpieczeństwa pojazdu z hamulcem ciernym sterowanym pneumatycznie $w$ ramach sprawdzonych od lat i wymaganych dzisiaj warunków dopuszczenia pojazdów do ruchu.

Hamulec cierny sterowany pneumatycznie jest sprawdzonym i przewidywalnym systemem hamulca, zapewniającym wysoki stopień bezpieczeństwa pociagu w hamowaniach służbowych, nagłych, uruchamianych w nagłych przypadkach przez pasażerów i wymuszonych innymi układami (SHP, czuwak czy radiostop). Ten typ hamulca stosowany jest również we wszystkich liniowych lub manewrowych lokomotywach jako dobrze stopniujący się hamulec bezpośredniego działania (hamulec dodatkowy).

Klasyczną formą hamulca sterowanego pneumatycznie jest hamulec klockowy, który na początku rozwoju kolejnictwa był stosowany w postaci klocków drewnianych, jednak już od dawna z powodu niewystarczającej odporności na temperaturę i niskie współczynniki tarcia na „mokro” został zastapiony 
klockami żeliwnymi. W trakcie wielu dziesiątków lat eksploatacji zwiększano odporność na zużycie klocków (wstawek) żeliwnych poprzez podniesienie zawartości fosforu. Dalsze poszukiwania wstawek o małym zużyciu (wyższej żywotności eksploatacyjnej) i o bardziej stałym przebiegu współczynnika tarcia $\mathrm{w}$ funkcji prędkości, stały się powodem rozwoju $\mathrm{w}$ drugiej połowie XX wieku wielu rodzajów klocków z tworzyw kompozytowych i ze spieków. Znalazły one szerokie zastosowanie w pojazdach szynowych, jakkolwiek budziły na początku wiele wątpliwości i zastrzeżeń, które wynikały przede wszystkim z konieczności wdrożenia nieco innej techniki prowadzenia pociagów zbliżonej do tej jaką stosować trzeba dla hamulca tarczowego. Wstawki z tworzyw kompozytowych są powszechnie stosowane od wielu lat w pojazdach trakcyjnych i wagonach osobowych $z$ kołami obręczowanymi dla niedużych prędkości i nacisków na oś (do $120 \mathrm{~km} / \mathrm{h}$ i do 16 ton) jak lokomotywy manewrowe, zespoły trakcyjne np. SBahn w DB, wagony osobowe Federacji Rosyjskiej, a ostatnio są wdrażane w całej Europie również w wagonach towarowych $\mathrm{z}$ kołami całowalcowanymi dla prędkości maksymalnej $120 \mathrm{~km} / \mathrm{h}$ i nacisków na oś zestawu kołowego 22,5 tony. Wagony $\mathrm{z}$ tymi wstawkami eksploatowane są w każdych warunkach klimatycznych, a wieloletnie doświadczenia kolei europejskich w stosowaniu wstawek kompozytowych stało się podstawą do opracowania przez podkomisję hamulcową UIC (5T „Hamulce”) obowiązujących wytycznych do bezpiecznego eksploatowania tych wstawek [1] ze względu na większe podobieństwo zachowania się wstawek kompozytowych do hamulca tarczowego niż do hamulca klockowego ze wstawkami żeliwnymi eksploatowanymi dotychczas (w zakresie parametrów trybologiczne i ze względu na zachowanie się w okresie zimy). Głównym powodem wdrażania do wagonów towarowych wstawek $\mathrm{z}$ tworzyw kompozytowych jest konieczność zredukowania hałasu pojazdów szynowych (pociagów). Rozwiązanie to znalazło duże zainteresowanie jako rozwiązanie alternatywne $\mathrm{w}$ stosunku do hamulca tarczowego, gdyż oba rozwiązania w równym stopniu skutecznie eliminuja hałas toczenia i hamowania pojazdu, przy czym hamulec klockowy jest bardziej interesujący ze względu na bardzo niskie koszty produkcji i eksploatacji. Mimo to hamulec tarczowy jest dzisiaj dominującą formą budowy hamulca $w$ wagonach osobowych i pojazdach trakcyjnych wszędzie tam, gdzie wymagane są bardzo duże moce hamowania, które występują $\mathrm{w}$ taborze dalekobieżnym, poruszającym się z prędkościami 160, 200 $\mathrm{km} / \mathrm{h}$ i więcej.

\section{Obciążenia cieplne i mechaniczne hamowanego koła}

$\mathrm{W}$ procesie hamowania pojazdu zamieniana jest jego energia kinetyczna $\mathrm{w}$ inne postacie energii $\mathrm{w}$ celu zmniejszenia jego prędkości lub zatrzymania.
W układach ciernych hamulca przede wszystkim na następujące postacie energii:

- ciepło

- odkształcenia sprężyste i plastyczne

- drgania

- nośność hydrodynamiczną

- przenikanie i pochłanianie molekuł par ciernych

- topnienie,

- rekrystalizację

- rozpad i powstawanie związków chemicznych zarówno na powierzchni tarcia jak i w głębi materiałów par ciernych itp.

Im większy jest udział energii cieplnej w stosunku do innych rodzajów energii w rozpraszanej energii pojazdu podczas hamowania, tym para cierna ma mniejsze zużycie. Zdecydowana większość energii pojazdu $\mathrm{w}$ procesie hamowania jest zamieniana na energię cieplną. Energia ta rozpraszana jest $\mathrm{w}$ skończonym czasie (hamowania), prowadząc do powstania dużych mocy hamowania realizowanych przez parę cierna. Na rys.1 pokazano przykładowe przebiegi chwilowych mocy hamowania dla różnych pojazdów szynowych podczas hamowania nagłego (do zatrzymania) realizowane przez jedno koło lub tarczę.

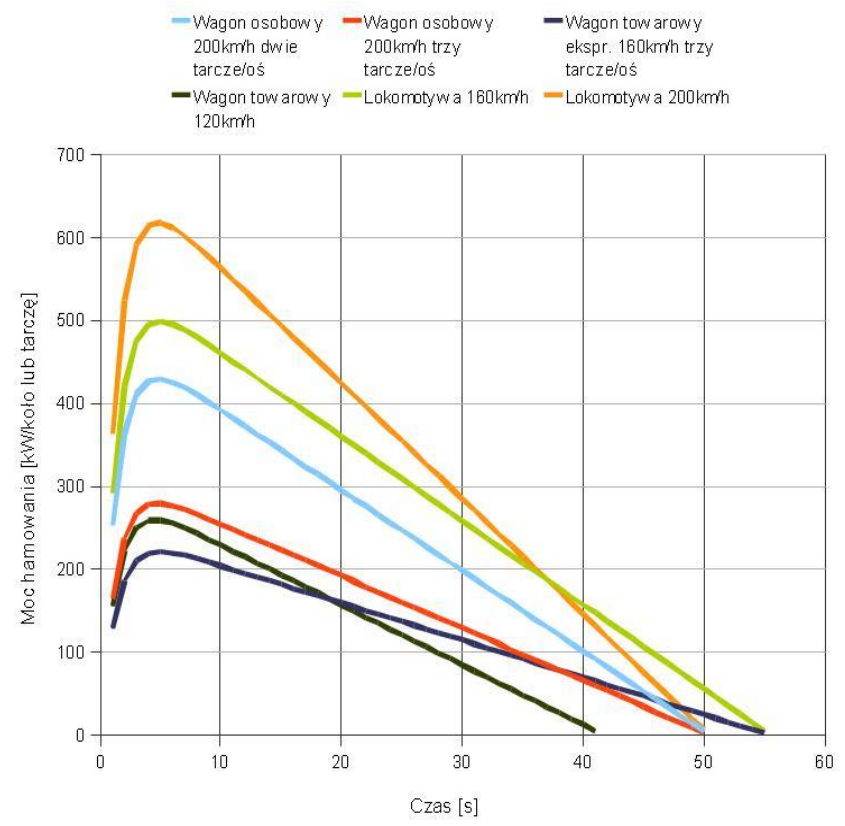

Rys.1 Poglądowy przebieg chwilowych mocy hamowania przypadających na jedną tarczę lub koło w funkcji czasu hamowania dla różnych pojazdów szynowych (dla hamowań do zatrzymania ze stałym maksymalnym opóźnieniem).

Powstałe w tym procesie ciepło dzieli się na dwa główne strumienie: wpływający do koła i do wstawki (lub tarczy i okładziny).

Współczynnik rozdziału strumienia cieplnego dla koła hamowanego wstawką hamulca klockowego wynosi szacunkowo[2]: 


$$
\alpha_{k}=\frac{1}{1+\frac{A_{k l o c k a}}{A_{k}} \sqrt{\frac{\lambda_{k l} \cdot \gamma_{k l} \cdot c_{k l}}{\lambda_{k} \cdot \gamma_{k} \cdot c_{k}}}}
$$

gdzie: $A_{\text {klocka }}$ - powierzchnia tarcia klocka (wstawki), $A_{k}-$ powierzchnia współpracy koła $\mathrm{z}$ klockiem,

$\lambda, \gamma, \mathrm{c}$ - przewodność cieplna, masa właściwa i ciepło właściwe odpowiednio materiału klocka i koła.

Dla parametrów geometrycznych i cieplnych hamulca klockowego żeliwnego lub ze spieków współczynnik $\alpha_{k}$ wynosi około 0,7 ; to znaczy, że około $70 \%$ energii cieplnej wpływa do koła (a około 30\% do wstawki i do otoczenia). Dla hamulca klockowego kompozytowego (z tworzyw sztucznych), przede wszystkim ze względu na mniejszy współczynnik przewodności $\lambda_{\mathrm{kl}}$ wstawki, współczynnik $\alpha_{\mathrm{k}}$ może wynosić nawet około 0,9 .

Wstawka z żeliwa (szczególnie niezbyt zużyta o dużej grubości), nagrzewając się na niewielką głębokość podczas pierwszych kilkudziesięciu sekund hamowania, doznaje odkształcenia na skutek pojawiającego się gradientu temperatury w kierunku jej grubości, który powoduje wewnętrzne naprężenia termiczne. Na skutek tego powstaje odkształcenie wstawki powodujące bardzo istotne zmniejszenie powierzchni rzeczywistego kontaktu wstawki z kołem. Na rys.2 pokazano fotografię powierzchni tarcia wstawki żeliwnej po hamowaniach nagłych, na której widać wyraźne zmniejszenie się rzeczywistej powierzchni kontaktu i ślady uplastyczniania się materiału w środkowej części wstawki na skutek bardzo wysokich temperatur.

$\mathrm{W}$ kole natomiast powstający gradient temperatury $\mathrm{w}$ głąb materiału koła prowadzi do wytworzenia się ściskających naprężeń termicznych na jego powierzchni. Naprężenia te (dla bardzo dużych prędkości i dużych opóźnień pojazdu) mogą osiągnąć wartość ponad $400 \mathrm{~N} / \mathrm{mm}^{2}$ [4].

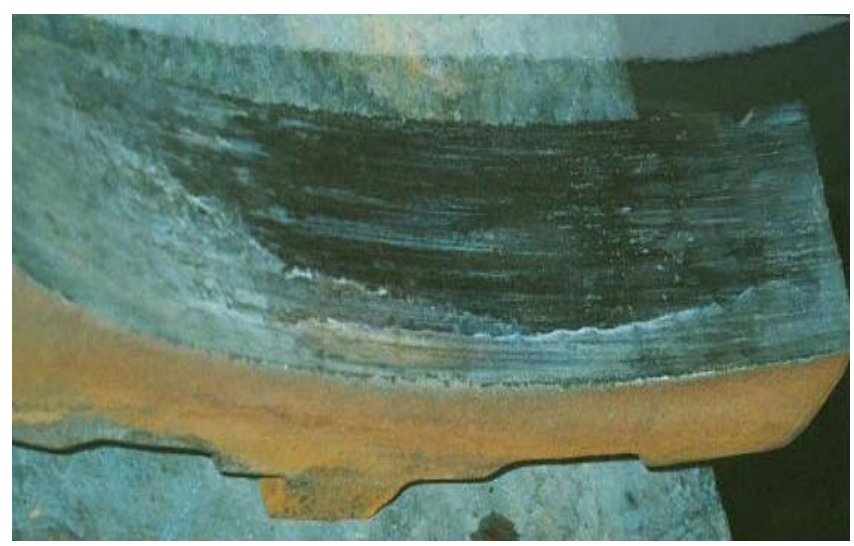

Rys.2 Powierzchnia wstawki żeliwnej po próbach hamowania nagłego
Odkształcenie wstawki prowadzi do zwiększenia jednostkowego strumienia cieplnego $\left(\mathrm{kW} / \mathrm{cm}^{2}\right)$ wpływającego zarówno do wstawki jak i do koła. Prowadzi to do powstania miejscowych wysokich temperatur na powierzchni tocznej kół, co $\mathrm{w}$ powiązaniu $\mathrm{z}$ dużą twardością żeliwa prowadzącą do pojawienia się zjawiska zogniskowanej niestabilności termosprężystej powoduje powstawanie tzw. miejscowych przegrzań - hot spot. W takiej sytuacji miejscowe temperatury na powierzchniach ciernych wstawki i koła mogą przekraczać $1000^{\circ} \mathrm{C}$ co prowadzi do nadmiernych zużyć pary ciernej. Pojawienie się tak wysokich temperatur wywołuje również intensywne iskrzenie, a niekiedy nawet zapłon produków zużycia, co powodować może pożary terenów przytorowych. Zjawisko iskrzenia i zapłonu produktów zużycia wstawki żeliwnej podczas badań na stanowisku bezwładnościowym pokazano na fotografii rys 3 .

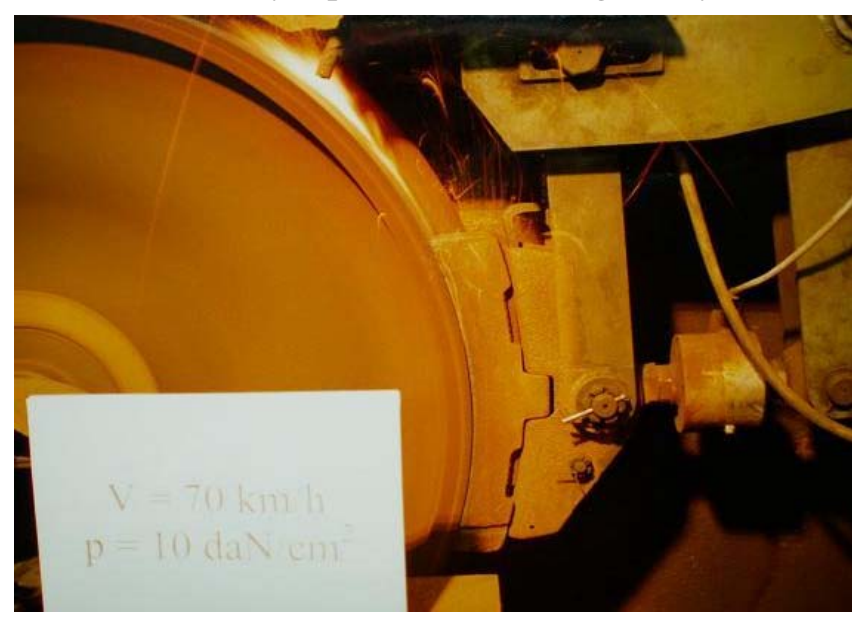

Rys.3 Zapłon produktów zużycia na skutek zogniskowanej niestabilności termosprężystej wstawki żeliwnej podczas hamowania nagłego (prędkość początku hamowania $70 \mathrm{~km} / \mathrm{h}$, nacisk jednostkowy $10 \mathrm{daN} / \mathrm{cm}^{2}$, masa $12 \mathrm{t} / \mathrm{koło}$ )

Wstawki ze spieków i z materiałów kompozytowych (na bazie tworzyw sztucznych) nie odkształcają się tak jak wstawki żeliwne, lepiej współpracują $\mathrm{z}$ powierzchnią toczną koła, a przy właściwie dobranych parametrach ich materiału np. twardości, modułu odkształcenia postaciowego, zużycia, przewodności cieplnej itd. nie wywołują zjawiska zogniskowanej niestabilności termosprężystej koła, dzięki czemu temperatury miejscowe i ich gradienty w kole są dużo niższe podczas hamowania $\mathrm{w}$ porównaniu ze wstawkami z żeliwa i nie stwarzają zagrożenia pożarowego. Przykładową zależność granicznej twardości okładziny kompozytowej w funkcji prędkości pojazdu nie powodującej zogniskowanej niestabilności termosprężystej pokazano na rys.5 [3]. Na rys.4 pokazano koło i wstawki ze spieków podczas badań na stanowisku bezwładnościowym pary ciernej przeznaczonej dla modernizowanej lokomotywy EP07 (parametry hamowania nagłego: prędkość początkowa $180 \mathrm{~km} / \mathrm{h}$, masa $11 \mathrm{t} /$ koło, naciski jednostkowe wstawki na koło $\left.9,4 \mathrm{daN} / \mathrm{cm}^{2}\right)$. 


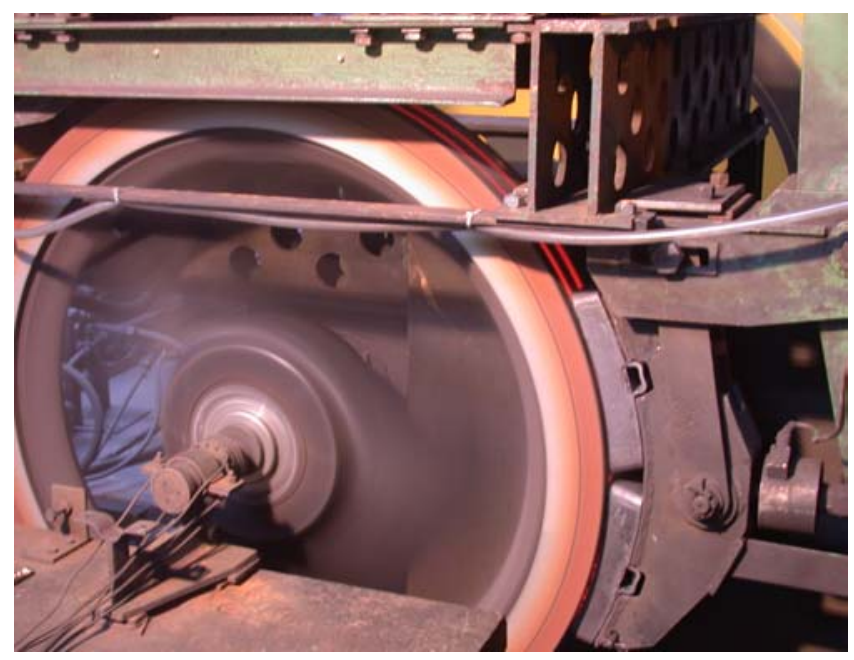

Rys.4 Hamowanie nagłe wstawkami ze spieków na stanowisku bezwładnościowym; badania dla modernizowanej lokomotywy EP07 ze wstawkami Carbone Lorraine 4x250 UIC250, materiał wstawek $\mathrm{C} 17$

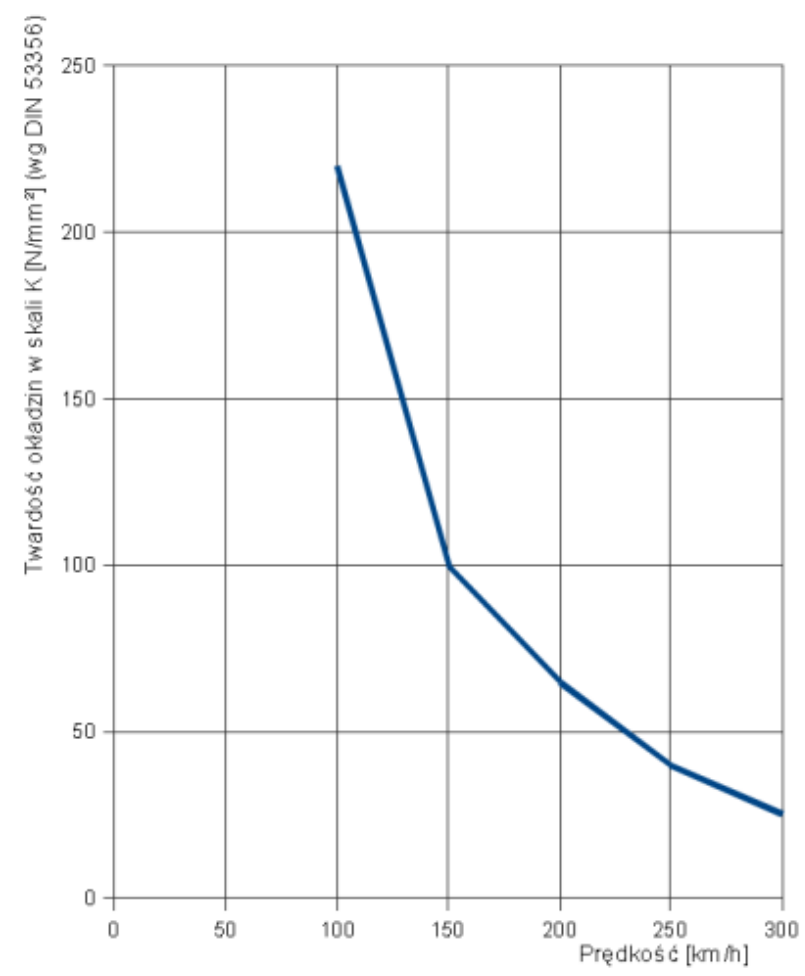

Rys.5 Graniczna twardość organicznych okładzin hamulca tarczowego w funkcji prędkości pojazdu nie powodująca zogniskowanej niestabilności termosprężystej tarcz

Badania wykazały pełną przydatność wstawek ze spieków dla lokomotyw o prędkości maksymalnej nawet $180 \mathrm{~km} / \mathrm{h}$. Badane wstawki posiadały dobrze dobrane parametry materiału i nie powodowały zognis-kowanej niestabilności termosprężystej koła tak jak wstawki z żeliwa (przy dużo niższej prędkości) i mając współczynnik przewodności cieplnej zbliżony do żeliwa wywołały odpowiednio niższe miejscowe temperatury w kole, a tym samym niższe naprężenia cieplne. Przeprowadzone obliczenia i pomiary średniej temperatury obręczy podczas hamowań nagłych wykazały, że również nie ma żadnego niebezpieczeństwa poluzownia się obręczy koła podczas hamowania lokomotywy z tej prędkości. Potwierdziło to dane przedstawione w [7] (strona 741) gdzie podano, że dla koła wagonowego (o średnicy $920 \mathrm{~mm}$ ) przy grubości obręczy $35 \mathrm{~mm}$ maksymalna prędkość hamowania nagłego bez obawy poluzowania obręczy dla pojazdu o masie 20t/oś wynosi $170 \mathrm{~km} / \mathrm{h}$ (dla wcisku 1,5\% i przy opóźnieniu hamowania $1,2 \mathrm{~m} / \mathrm{s}^{2}$ ), a dla wcisku 2\%o $195 \mathrm{~km} / \mathrm{h}$. Biorąc pod uwagę, że pojemność cieplną obręczy koła lokomotywowego (o średnicy $1250 \mathrm{~mm}$ ) która jest większa o około 1,5 raza $\mathrm{W}$ porównaniu $\mathrm{z}$ wyżej omawianym kołem wagonowym, graniczna prędkość przy której nastapi zluzowanie obręczy podczas hamowania do zatrzymania lokomotywy jest większa niż $200 \mathrm{~km} / \mathrm{h}$.

W wyniku toczenia się kół po szynie w miejscu styku koła i szyny pojawiają się naprężenia zwane naprężeniami kontaktowymi. Naprężenia te, występujące na niewielkim obszarze koła, również są ściskające (tak jak naprężenia termiczne) i osiagają znaczne wartości. Na skutek toczenia się kół po szynie wartość tych naprężeń zależy od prędkości, nacisku koła na szynę i od średnicy koła. Przekraczają one granicę plastyczności materiału koła na głębokości kilku milimetrów. Naprężenia zredukowane $o_{\varphi} \mathrm{W}$ tym obszarze są proporcjonalne do wspó-

łczynnika $\sqrt{\varphi \frac{Q}{D}}$, gdzie: $\varphi$ jest współczynnikiem zależnym przede wszystkim od prędkości jazdy, Q obciążeniem koła, a D - średnicą koła. Naprężenia te osiagają wartość około $350 \mathrm{~N} / \mathrm{mm}^{2}$ [4]. Dodatkowo koła obciążone są stycznymi siłami od poślizgów wzdłużnych, poprzecznych i wiertnych.

\section{Graniczna obciążalność koła hamowanego ha- mulcem klockowym i najczęściej spotykane uszkodzenia powierzchni tocznej kół}

Obciążenia cieplne i mechaniczne materiału koła wyznaczają granice stosowalności hamulca klockowego pokazaną na rys.6 [4].

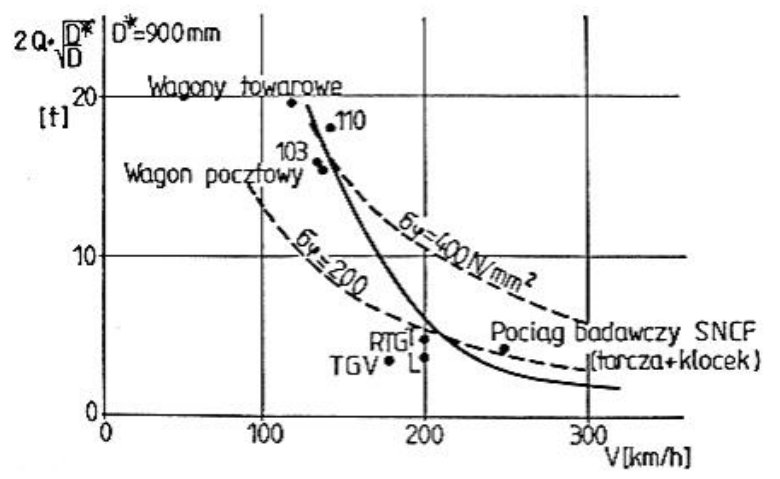

Rys.6 Graniczne obciążenia pary ciernej koło - klocek żeliwny pojazdów szynowych [3] 
Superpozycja wyżej opisanych obciążeń prowadzi bowiem do przekroczenia granicy plastyczności na powierzchni tocznej oraz na głębokości kilka milimetrów pod powierzchnią toczną koła. Przekroczenia te powodują (już po kilkudziesięciu intensywnych hamowaniach) pojawienie się siatki termicznych pęknięć powstającej podczas procesu stygnięcia koła. $\mathrm{Na}$ rys.7 pokazano typową siatkę pęknięć koła współpracującego ze wstawkami kompozytowymi. W dalszej eksploatacji pojazdu występuje wykruszanie się materiału obręczy kół z powierzchni tocznej tzw. pitting kół, pokazany na rys.8.

Zjawiska te pojawiają się na kołach intensywnie hamowanych zarówno we współpracy ze wstawkami żeliwnymi jak i ze wstawkami kompozytowymi. W przypadku wstawek żeliwnych obserwacja początkowych pęknięć termicznych jest utrudniona ze względu na ich zacieranie przez klocek (rowkowanie koła i tworzenie się połączeń adhezyjnych żeliwnych produktów zużycia $\mathrm{z}$ materiałem koła), ale drugi etap uszkodzeń tzw. pitting kół jest zjawiskiem powszechnie obserwowanym w lokomotywach i wagonach intensywnie eksploatowanych $\mathrm{z}$ większymi prędkościami.

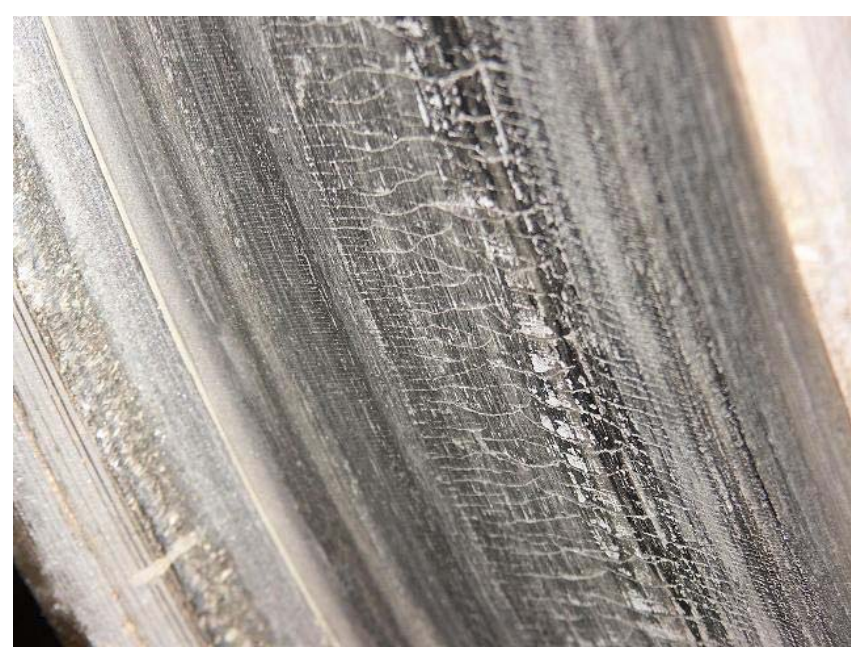

Rys.7 Siatka termicznych pęknięć na powierzchni koła

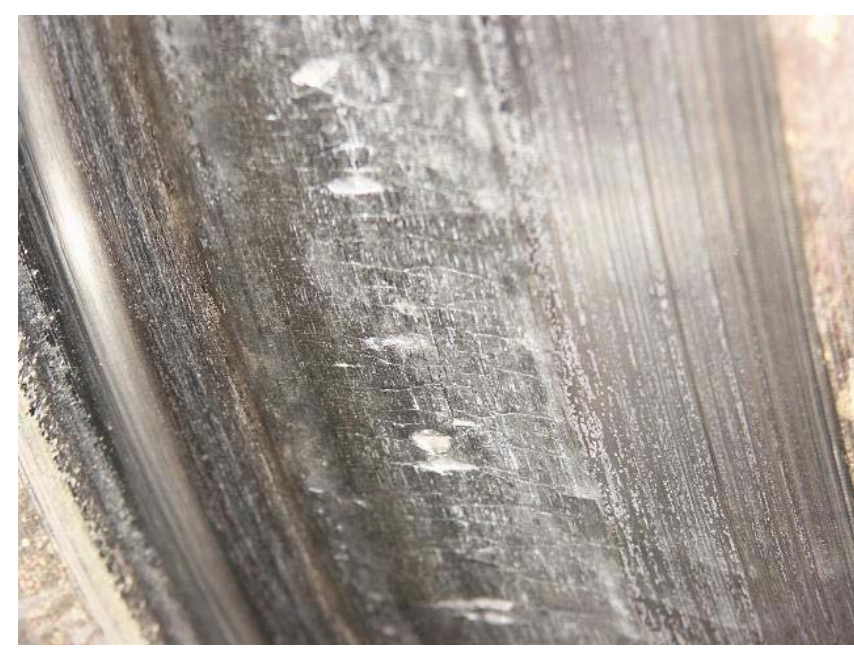

Rys. 8 Wykruszenia materiału powierzchni tocznej koła tzw. pitting
Wprowadzanie ciepła przez wstawkę podczas hamowania nie jest jedynym źródłem wprowadzania obciążeń cieplnych kół. Groźne okazują się również poślizgi kół po szynie [4] w trakcie zarówno rozruchu jak i hamowania. Na rys.9 pokazano przegrzanie miejscowe wywołane poślizgiem; granatowa obwódka niewielkiego płaskiego miejsca (na zdjęciu widoczna jako ciemna obwódka w obszarze płaskiego miejsca) wskazuje na przekroczenie temperatury $450^{\circ} \mathrm{C}$.

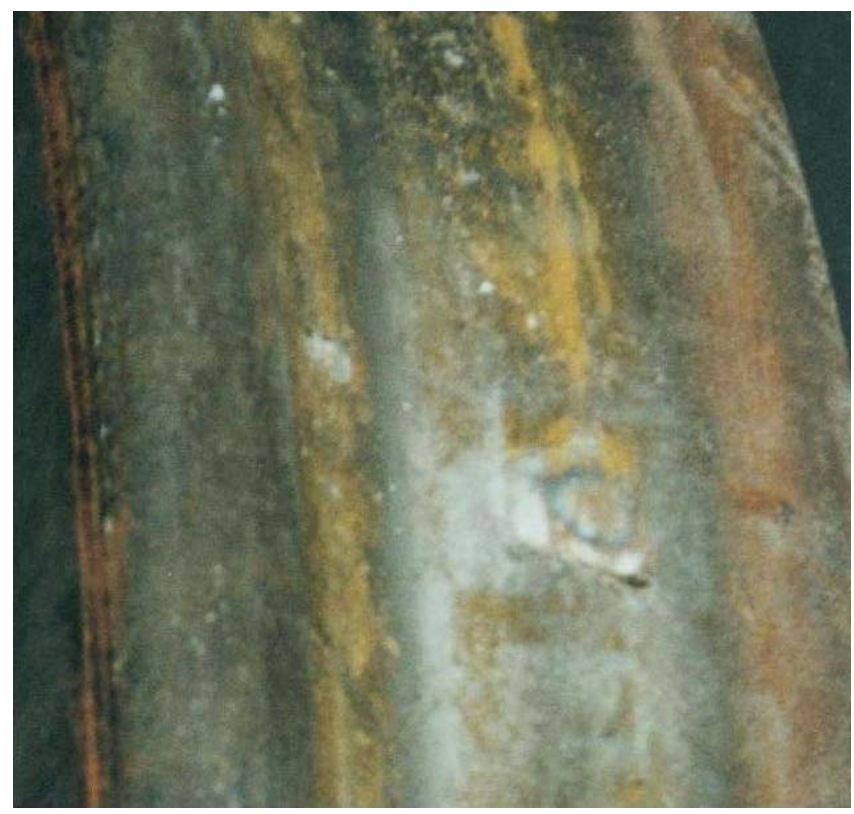

Rys.9 Przegrzanie miejscowe na powierzchni tocznej koła w wyniku poślizgu

Uszkodzenia $\mathrm{W}$ postaci wykruszeń materiału $\mathrm{Z}$ powierzchni tocznej koła (tzw. pitting koła) na skutek takiego obciążenia mogą się pojawić już po paru miesiącach niewłaściwej eksploatacji (np. po intensywnych rozruchach lub hamowaniach z blokada kół występujących przy większych prędkościach) i to bez stwierdzenia wyraźnych płaskich miejsc na kołach. Uszkodzenia takie obserwuje się często na kołach lokomotyw, napędnych kołach zespołów trakcyjnych, ale również na kołach wagonów osobowych wyposażonych w hamulec tarczowy!

Opisane wyżej uszkodzenia kół stanowią do dziś bardzo poważny problem w eksploatacji taboru kolejowego, szczególnie w zarządach, które nie partycypują w rozwoju nowych rozwiązań konstrukcyjnych i nowych materiałów wdrażanych do eksploatacji, oraz nie wdrażają nowych technik eksploatacji.

\section{Metody ograniczania występujących uszkodzeń kól i prace aktualnie prowadzone w tym zakresie}

W celu ograniczenia omówionych uszkodzeń kół, w pojazdach eksploatowanych z dużymi prędkościami i o dużych opóźnieniach hamowania, hamowanych klockami, 
- montuje się nowoczesne układy przeciwpoślizgowe działające zarówno przy rozruchu jak i podczas hamowania,

- wprowadza się wysokowydajny hamulec elektrodynamiczny,

- rejestruje się każde bardzo intensywne hamowanie wykonane tylko hamulcem klockowym, po którym wykonuje się płytkie przetoczenie [5],

- zmienia się materiał kół na bardziej odporny na pękania kruche i o większej wytrzymałości.

Dzięki takim działaniom mimo podniesienia prędkości eksploatacyjnej pojazdów trakcyjnych wyposażonych w hamulec klockowy, nie powstają opisane uszkodzenia kół a nawet niektórym zarządom kolejowym udało się istotnie wydłużyć przebiegi lokomotyw hamowanych hamulcem klockowym. Przykład lokomotywy elektrycznej S 252 hiszpańskich kolei RENFE pokazuje, że przy pomocy takich eksploatacyjnych działań prewencyjnych $\mathrm{z}$ zakresu eksploatacji i technicznych warunków utrzymania taboru, żywotność kół może przekroczyć milion kilometrów przebiegu lokomotywy [6].

Podobne działania planuje się zastosować podczas modernizacji polskiej lokomotywy EU07 realizowanej przez IPS Tabor i ZNTK Oleśnica $w$ ramach projektu celowego 04490/C.ZR6-6/2009. W ramach projektu realizowane są:

- analizy możliwości wykorzystania nowych systemów i układów krajowych,

- obliczenia i badania symulacyjne nowych układów,

- badania wykonanych modeli układów w skali $1: 1$

- prace nad dokumentacją układów,

- badania nowo-opracowanych układów.

W wyniku prowadzonych prac powstanie w ZNTK Oleśnica lokomotywa EP07 o prędkości maksymalnej $160 \mathrm{~km} / \mathrm{h}$, na której $\mathrm{w}$ systemie hamulca zostaną zastosowane:

- elektroniczne układy przeciwpoślizgowe podczas rozruchu i podczas hamowania,

- wstawki ze spieków na duże prędkości o zwiększonym współczynniku tarcia w celu zapewnienia, przy zachowaniu dotychczasowego układu mechanicznego hamulca na wózku, wymaganej skuteczności hamulca (dla większej prędkości maksymalnej opóźnienia hamowania lokomotywy muszą wynosić dla nastawienia ,pospieszny” około $1,1 \mathrm{~m} / \mathrm{s}^{2}$ ),

- cylindry hamulcowe $\mathrm{z}$ nastawiaczami skoku tłoka o średnicy 10 " z hamulcem postojowym sprężynowym, zapewniające utrzymanie lokomotywy na pochyleniu 40 promil,
- nieco większe wciski obręczy na kole (1,6 1,8 promil) i obręcze zestawów kołowych $\mathrm{z}$ materiału P60 lub P70, w celu zapewnienia takiego samego bezpieczeństwa przed poluzowaniem się obręczy jaki występuje na dotychczas eksploatowanych lokomotywach EU07,

- asynchroniczny układ napędu i hamulca elektrodynamicznego,

- mikroprocesorowe sterowanie zapewniające wymaganą współpracę (blending) skutecznego hamulca elektrodynamicznego (ED) $\mathrm{z}$ hamulcem klockowym oraz możliwość rejestracji hamowań pełnych lub nagłych zrealizowanych $\mathrm{z}$ wyłączo-nym hamulcem ED, w celu wykonania prewen-cyjnego przetoczenia powierzchni tocznej kół w krótkim czasie po takim zdarzeniu.

Właściwy dobór parametrów wytrzymałościowych, cieplnych i ciernych hamulca oraz układu napędowego modernizowanej lokomotywy, został potwierdzony uzyskanymi wynikami badań w skali $1: 1$ i obliczeniami przeprowadzonymi metodą elementów skończonych.

\section{Zakończenie}

Hamulce klockowe i tarczowe w najbliższej przyszłości będą nadal powszechnie stosowanymi rodzajami hamulców, przy czym ich zakres stosowania w zależności od technicznej i ekonomicznej przewagi coraz bardziej będzie się rozdzielał.

Dla pojazdów bez napędu i $z$ niewielkimi wymaganiami co do mocy hamowania (do około $450 \mathrm{~kW}$ na zestaw kołowy), hamulec klockowy jest konstrukcyjnie najprostszym i zasadnym rozwiązaniem, szczególnie dla wagonów towarowych. Rozwój wstawek kompozytowych o niskim współczynniku tarcia, podobnym do wstawek $\mathrm{z}$ żeliwa szarego, zapewni zmniejszenie hałasu $w$ wagonach towarowych i innych pojazdach o prędkości maksymalnej do $120 \mathrm{~km} / \mathrm{h}$ poprzez prosta wymianę wstawek bez dużych nakładów.

Dla bardzo dużych mocy hamowania (ponad $650 \mathrm{~kW}$ na zestaw kołowy) - i w przyszłości być może również dla jeszcze większych mocy - stosowane będą hamulce tarczowe, gdyż tylko one są w stanie skutecznie i w dłuższym czasie eksploatacji zagwarantować odprowadzenie ciepła bez niedopuszczalnych (niebezpiecznych) naprężeń w kołach prowadzących do ich uszkodzeń. W pojazdach trakcyjnych na prędkości $120 \div 200 \mathrm{~km} / \mathrm{h}$, a szczególnie w pojazdach modernizowanych posiadających hamulec klockowy, które wyposażane są dodatkowo w hamulce dynamiczne dużej mocy spełniające wymagania umożliwiające uwzględnienie ich w ogólnej skuteczności hamowania pojazdu (co jest dzisiaj 
przypadkiem powszechnym), może okazać się, że hamulec klockowy ze względu na swoją prostotę i niskie koszty eksploatacji jest najlepszym rozwiązaniem. W takich pojazdach cierne hamulce pneumatyczne nie muszą być intensywnie używane, a w przypadku ich wdrożenia (bez współdziałania $\mathrm{z}$ hamulcami elektodynamicznymi) będzie zagwarantowane, by po każdym intensywnym hamowaniu (nagłym i zbliżonym do pełnego) tylko hamulcem klockowym, nastapiło w krótkim czasie po tym zdarzeniu, niezbyt głębokie przetoczenie powierzchni tocznej kół. Określenie tych hamowań przez sterownik mikroprocesorowy pojazdu jest dzisiaj tak samo proste do zrealizowania jak sterowanie hamulcem ciernym zapewniającym właściwą współpracę z hamulcem elektrodynamicznym (blending). Współpraca ta powoduje, że hamulec klockowy spełnia rolę „hamulca czyszczącego”, który kondycjonuje powierzchnię toczną kół, utrzymuje przez to wysoki współczynnik przyczepności koło-szyna, zapewniając dużą siłę pociągową pojazdu. Dzięki stosowanej na pojazdach trakcyjnych technice mikroprocesorowej granica stosowalności hamulca klockowego uległa przesunięciu w kierunku większych prędkości i hamulec ten może być jeszcze długo stosowany w pojazdach szynowych .

\section{Literatura}

[1] Ausschuss CTR Technik und Forschung. Unterausschuss 5T „Bremswesen“. UIC - Frage 5T53: Lärmreduzierung - Einbau von Verbundstoffsohlen in Güterwagen.Teil 2. Bremsbetrieb, Überwachung und Instandhaltung. 29.05.2001

[2] Kazarinov V.M., Inoziemcev V.G., Jasiencev V.F.: Teoreticzeskije osnowy projektirowania i eksptuatacji avtotarmozov. Izdatielstwo „Transport” 1968

[3] Otto A.W.: Stand der Entwicklung von Bremswerkstoffen für Schienenfahrzeuge. ZEV+DET Glas. Ann. 119 (1995) $n r$ 11/12/05

[4] Saumweber E.: Leistungsgrenzen Kombinierter Bremssysteme. ZEV-Glas. Ann. Nr 7/8, 1974

[5] Hans-Reinhard Ehlers, Kröppelhagen, Ekkehard Gärtner, Hennigsdorf : Potenziale und Grenzen der Klotzbremse im Vergleich zur Scheibenbremse. ZEV+DET Glas. Ann. 126 (2002) 6/7

[6] Zander,C.: Klotzbremsen mit Sintermetallbelägen Betriebserfahrungen mit Hochleistungslokomotiven. ZEV+DET Glas. Ann. 125 (2001) 4

[7] Karl Sachs: Elektrische Triebfahrzeuge, Erster Band: Allgemeine Grundlagen und Mechanischer Teil, Springer-Verlag, Wien New Jork, 1973 